\title{
Epidemiological analysis of diseases of children and adolescents requiring neurological and mobility rehabilitation in the Świętokrzyskie Rehabilitation Center in Czarniecka Góra, Poland
}

\author{
Marek L Grabowski', Bożena Kosińska², Józef P Knap³, Zbigniew Lewandowski \\ ${ }^{1}$ Department of Nursing, School of Management, Częstochowa, Poland \\ ${ }^{2}$ The Independent Regional Public Psychiatric Hospital, Radom, Poland \\ ${ }^{3}$ Department of Epidemiology, Institute of Social Medicine, Warsaw Medical University, Poland
}

Grabowski ML, Kosińska B, Knap JP, Lewandowski Z. Epidemiological analysis of diseases of children and adolescents requiring neurological and mobility rehabilitation in the Świętokrzyskie Rehabilitation Center in Czarniecka Góra, Poland. Ann Agric Environ Med. 2016; 23(2):259263. doi: 10.5604/12321966.1203887

\begin{abstract}
Introduction and objective. Epidemiological analysis of the dynamics of admissions and patient characteristics is presented concerning 5,955 children and adolescents (3-18 years of age) hospitalized in 2007-2013 with neurological and mobility diseases in Świętokrzyskie Rehabilitation Centre (ŚRC) in southern Poland.

Materials and method. Within the period of 7 years, 18,647 patients were admitted to the ŚRC, of whom 9,546 were admitted to the daily ward and 9,109 to the stationary wards. 5,955 were children and adolescents aged 3-18, 1,499 were children aged 3-13 and almost three times more were patients aged 14-18. The correlation between the number of admissions in each year and the number of those hospitalized depending on the age and diagnosis was examined.

Results. In the discussed period, in both age ranges, the group of deforming dorsopathies dominated, while cerebral palsy was the second most common cause of hospitalization, and the and post-traumatic disorder the smallest number. In the diagnoses of cerebral palsy and post-traumatic disease, boys constituted most of the hospitalized. In contrast, girls dominated in the group of deforming dorsopathies.

Discussion. Analysis of the material of 5,955 patients revealed a number of quantitative data which assisted in the analysis of the epidemiological situation of this group of diseases - necessary for the planning of highly specialized treatment and rehabilitation. The greatest needs in terms of admissions to the ŚRC concerned the group of adolescents aged 14-18. The results of combined rehabilitation indicated the full use of places in the Świętokrzyskie Rehabilitation Center and also indicated the need for similar provincial and even regional centres.
\end{abstract}

Key words

childrens' and adolescent rehabilitation, rehabilitation centre, cerebral palsy, epidemiological analysis

\section{INTRODUCTION}

The Świętokrzyskie Rehabilitation Center (ŚRC) in Czarniecka Góra is a large modern rehabilitation centre, the only one in Świętokrzyskie Province (formerly Kieleckie Province) in southern Poland, specialising in the mobility and neurological rehabilitation of children and adolescents aged from 3-18 years $[1,2,3]$. Because of this specialization, the institution has also become a supra-regional centre in which children and adolescents suffering from cerebral palsy, congenital spine diseases and traumatic injuries in this age group are hospitalized (in a not mentioned group of adults young people also dominate). Based on the analysis of 5,955 admissions in the age group of 3-18 year olds in a 7 year period (2007-2013), the epidemiological development of hospitalizations in the SRC and the structure of patients admitted with a diagnosis of the above-mentioned 3 groups is presented. These groups are combined together, despite their different ethiopathogenesis, due to the fact that they were the

Address for correspondence: Bożena Kosińska, The Independent Regional Public Psychiatric Hospital, Krychnowicka 1, 26-600 Radom, Poland

E-mail: bozko@vp.pl

Received: 06 July 2015; accepted: 08 December 2015 dominant group of patients, and also because of the methods of rehabilitation and treatment common to all of them.

\section{MATERIALS AND METHOD}

The ŚRC has 2 stationary wards with 80 beds, which admits children and adolescents under the age of 18 , and a daily ward with 120 places, where there is no age limit to admissions. Within the period of 7 years (2007-2013), 18,647 patients were admitted to the ŚRC - 9,546 to the daily ward, (Tab. 1). Within all wards, the patients benefit from all form of rehabilitation with physiotherapy, hydrotherapy, hippotherapy and a swimming pool. The patients in the stationary wards use the elementary and junior high schools at the centre. In the stationary wards a total of 9,109 patients were hospitalized, of whom 5,955 were children and adolescents aged 3-18 years who were the subject of this study. In this group, 1,499 patients were children aged 3-13 years, and almost three times as many - 4,456, were patients aged 14-18 (Tab. 1). Not included in the analysis analysed was a group of 3,114 hospitalized patients over the age of 18 . ongly dominated by young people. Table I also shows 3 analyzed groups of pathology: 
Table 1. Total number of patients admitted to ŚRC

\begin{tabular}{cccccc}
\hline Years & $\begin{array}{c}\text { No. of } \\
\text { admissions } \\
\text { to stationary } \\
\text { wards at age } \\
3-13\end{array}$ & $\begin{array}{c}\text { No. of } \\
\text { admissions } \\
\text { to stationary } \\
\text { wards at age } \\
14-18\end{array}$ & $\begin{array}{c}\text { No. of } \\
\text { admissions } \\
\text { to stationary } \\
\text { wards at age } \\
18+\end{array}$ & $\begin{array}{c}\text { No. of } \\
\text { admissions } \\
\text { to daily } \\
\text { ward }\end{array}$ & $\begin{array}{c}\text { Total No. of } \\
\text { admissions } \\
\text { to ŚRC }\end{array}$ \\
\hline 2007 & 274 & 559 & 377 & 1,700 & 2,910 \\
\hline 2008 & 252 & 601 & 376 & 1,789 & 3,018 \\
\hline 2009 & 224 & 594 & 367 & 1,755 & 2,940 \\
\hline 2010 & 214 & 584 & 435 & 1,373 & 2,606 \\
\hline 2011 & 191 & 605 & 418 & 989 & 2,203 \\
\hline 2012 & 163 & 821 & 555 & 994 & 2,533 \\
\hline 2013 & 181 & 692 & 618 & 946 & 2,437 \\
\hline Total & 1,499 & 4,456 & 3,146 & 9,546 & 18,647 \\
\hline
\end{tabular}

1) cerebral palsy - diagnostic codes G80-G81 according to the International Classification of Diseases ICD-10 [4];

2) deforming dorsopathies, mostly innate, but also acquired, e.g. perinatally (M40-M43): kyphosis and lordosis (M40), scoliosis (M41), spinal osteochondrosis (Scheuermann disease) (M42), and other deforming dorsopathies (M43);

3) injury, poisoning, and certain other consequences of external causes (S00-S99 and T00-T99). In the group S00-S99 there were injuries which were divided into anatomical areas: head, neck, thorax, abdomen, lower back, lumbar spine and pelvis, shoulder and upper arm, elbow and forearm, wrist and hand, hip and thigh, knees and lower leg, ankle and foot. In the group coded as T, there were mainly injuries involving multiple body regions and their effects (T00-T14) and the consequences and complications (T66-T98).

These diseases were diagnosed on the basis of generally accepted criteria. In all cases, a diagnosis made by specialized centres referring patients to the SRC were maintained. The numbers of admissions show de facto numbers of people because the centre adopted the principle of one hospitalization of a patient in a year. The results were statistically analysed. The correlation between the number of admissions in each year and the number of hospitalized depending on the age and diagnosis were examined.

\section{RESULTS}

In the discussed period, in both age groups, patients with deforming dorsopathies $(4,823)$ dominated, cerebral palsy was the second most common cause of hospitalization (901), with post-traumatic disorder the smallest number of admissions (231) (Tab. 2). The great majority of patients came from Świętokrzyskie Province (Tab. 1). In all the years, age groups, and groups of diagnoses, there are patients outside the Świętokrzyskie province, the highest percentage of hospitalized came from outside the Province and were suffering with cerebral palsy. For children it was 90 of 331 ill (27\%), for adolescents 132 of 570 (23\%), wherein for group of adolescents, the level of significance, saying that over the years the percentage of hospitalized outside the region changes, was significant in a statistical sense $(\mathrm{p}<.0001)$.

The reduction in the number of hospitalizations in 2011-2013 was caused by renovation work and significant

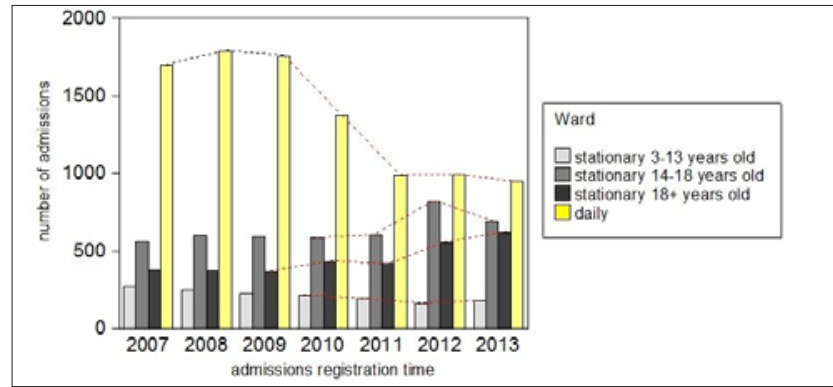

Figure 1. Number of admissions depending on the time, ward type and age of the patients.

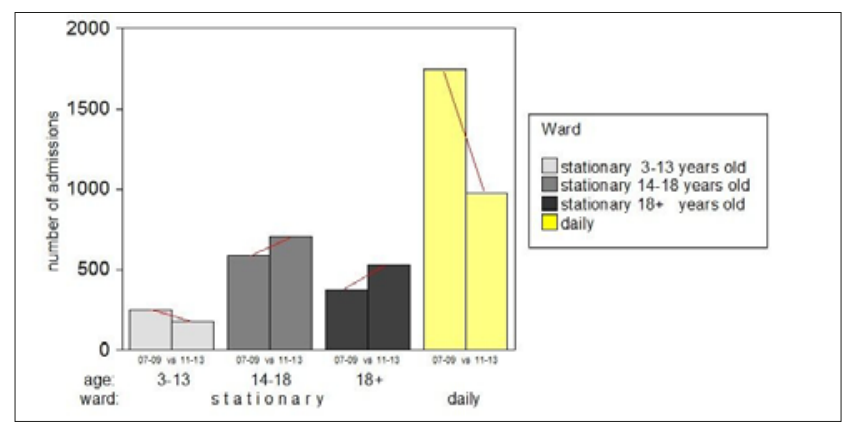

Figure 2. Number of admissions depending on the ward, time (before vs. during renovation) and age of patients

expansion of the centre, which included a new pavilion for patients and a modern rehabilitation department). The work was completed in 2013. In subsequent years, the total number of hospitalized decreased in a statistically significant way. In accordance with that trend, the number and percentage of admissions of younger children (3-13 years) to the stationary ward was reduced, and the overall reduction in the number of admissions was enforced by admissions of the youngest patients to stationary ward at the expense of admissions to the daily ward. In contrast, the number and percentage of teenagers (14-18 years) and those over 18 years of age admitted to the stationary ward increased. This increase was statistically significant. The need of admissions to a stationary ward people aged 14-18 years and 18+ caused, for undoubted satisfying the needs of hospitalization - transfer the "daily admissions" on stationary wards. Those necessary transfers were calculated as a corresponding difference in Table 3 . The decrease in admissions on a ward exceeding $40 \%$ forced the increase in the number of admissions to stationary ward.

In the two diagnosed groups, cerebral palsy, post-traumatic diseases, boys constituted most of the hospitalized. In contrast, the girls dominated in the group of deforming dorsopathies.

Table 3. Average number of admissions before and after renovation, depending on the ward and age of patients

\begin{tabular}{lccccc}
\hline \multirow{2}{*}{ Ward } & Age & $\begin{array}{c}\text { Before } \\
\text { renovation }\end{array}$ & $\begin{array}{c}\text { During } \\
\text { renovation }\end{array}$ & $\begin{array}{c}\text { Change in No. } \\
\text { of admissions }\end{array}$ & $\%$ \\
\cline { 2 - 5 } & $2007-2009$ & $2011-2013$ & & -30 \\
\hline \multirow{3}{*}{ Stationary } & $3-13$ & 250.0 & 178.3 & -72 & -30 \\
\cline { 2 - 6 } & $14-18$ & 584.7 & 706.0 & -122 & +20 \\
\cline { 2 - 6 } & $18+$ & 373.3 & 530.3 & -157 & +40 \\
\hline Daily & & 1748.0 & 976.3 & -772 & -40
\end{tabular}


Table 2. Number of stationary patients in Rehabilitation Wards I and II of Świętokrzyskie Rehabilitation Centre in Czarniecka Góra, according to the International Classification of Diseases (ICD-10)

\begin{tabular}{|c|c|c|c|c|c|c|c|c|c|c|c|}
\hline \multirow{2}{*}{ Year } & \multirow{2}{*}{ Origin } & \multirow{2}{*}{ Age range } & \multicolumn{3}{|c|}{ Cerebral palsy (G80-G81) } & \multicolumn{3}{|c|}{ Deforming dorsopathies (M40-M43) } & \multicolumn{3}{|c|}{ Traumatic injuries (S00-S99;T00-T99) } \\
\hline & & & Girls & Boys & Total & Girls & Boys & Total & Girls & Boys & Total \\
\hline \multirow{6}{*}{2007} & \multirow{2}{*}{ SP } & $3-13$ & 8 & 12 & 20 & 133 & 88 & 221 & 1 & 4 & 5 \\
\hline & & $14-18$ & 17 & 56 & 73 & 238 & 157 & 395 & 5 & 17 & 22 \\
\hline & \multirow{2}{*}{ OSP } & $3-13$ & 2 & 3 & 5 & 15 & 6 & 21 & 1 & 1 & 2 \\
\hline & & $14-18$ & 4 & 8 & 12 & 31 & 21 & 52 & 2 & 3 & 5 \\
\hline & \multirow{2}{*}{ Total } & $3-13$ & 10 & 15 & 25 & 148 & 94 & 242 & 2 & 5 & 7 \\
\hline & & $14-18$ & 21 & 64 & 85 & 269 & 178 & 447 & 7 & 20 & 27 \\
\hline \multirow{6}{*}{2008} & \multirow{2}{*}{ SP } & $3-13$ & 25 & 27 & 52 & 94 & 67 & 161 & 1 & 6 & 7 \\
\hline & & $14-18$ & 18 & 62 & 80 & 258 & 164 & 422 & 6 & 21 & 27 \\
\hline & \multirow{2}{*}{ OSP } & $3-13$ & 3 & 10 & 13 & 12 & 5 & 17 & 1 & 1 & 2 \\
\hline & & $14-18$ & 5 & 7 & 12 & 34 & 21 & 55 & 1 & 4 & 5 \\
\hline & \multirow{2}{*}{ Total } & $3-13$ & 28 & 37 & 65 & 106 & 72 & 178 & 2 & 7 & 9 \\
\hline & & $14-18$ & 23 & 69 & 92 & 292 & 185 & 477 & 7 & 25 & 32 \\
\hline \multirow{6}{*}{2009} & \multirow{2}{*}{ SP } & $3-13$ & 27 & 22 & 49 & 69 & 59 & 128 & 3 & 10 & 13 \\
\hline & & $14-18$ & 18 & 28 & 46 & 261 & 144 & 405 & 14 & 26 & 40 \\
\hline & \multirow{2}{*}{ OSP } & $3-13$ & 11 & 8 & 19 & 9 & 6 & 15 & 0 & 0 & 0 \\
\hline & & $14-18$ & 7 & 8 & 15 & 60 & 27 & 87 & 0 & 1 & 1 \\
\hline & \multirow{2}{*}{ Total } & $3-13$ & 38 & 30 & 68 & 78 & 65 & 143 & 3 & 10 & 13 \\
\hline & & $14-18$ & 25 & 36 & 61 & 321 & 171 & 492 & 14 & 27 & 41 \\
\hline & & $3-13$ & 23 & 29 & 52 & 72 & 46 & 118 & 1 & 3 & 4 \\
\hline & ה & $14-18$ & 23 & 23 & 46 & 277 & 141 & 418 & 5 & 13 & 18 \\
\hline & & $3-13$ & 3 & 14 & 17 & 12 & 11 & 23 & 0 & 0 & 0 \\
\hline 2010 & (5) & $14-18$ & 6 & 12 & 18 & 52 & 30 & 82 & 0 & 2 & 2 \\
\hline & Tra & $3-13$ & 26 & 43 & 69 & 84 & 57 & 141 & 1 & 3 & 4 \\
\hline & & 14-18 & 29 & 35 & 64 & 329 & 171 & 500 & 5 & 15 & 20 \\
\hline & S & $3-13$ & 17 & 20 & 37 & 59 & 41 & 100 & 2 & 6 & 8 \\
\hline & $\mathrm{SP}$ & $14-18$ & 20 & 28 & 48 & 270 & 139 & 409 & 2 & 15 & 17 \\
\hline & & $3-13$ & 6 & 16 & 22 & 17 & 7 & 24 & 0 & 0 & 0 \\
\hline 2011 & 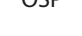 & $14-18$ & 6 & 14 & 20 & 71 & 32 & 103 & 3 & 5 & 8 \\
\hline & & $3-13$ & 23 & 36 & 59 & 76 & 48 & 124 & 2 & 6 & 8 \\
\hline & Tutar & $14-18$ & 26 & 42 & 68 & 341 & 171 & 512 & 5 & 20 & 25 \\
\hline & SD & 3-13 & 3 & 8 & 11 & 86 & 43 & 129 & 0 & 0 & 0 \\
\hline & I & 14-18 & 43 & 61 & 104 & 356 & 243 & 599 & 6 & 16 & 22 \\
\hline 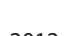 & Scr & $3-13$ & 1 & 7 & 8 & 9 & 6 & 15 & 0 & 0 & 0 \\
\hline 2012 & USP & $14-18$ & 10 & 24 & 34 & 33 & 27 & 60 & 1 & 1 & 2 \\
\hline & $T$ & $3-13$ & 4 & 15 & 19 & 95 & 49 & 144 & 0 & 0 & 0 \\
\hline & Toldal & $14-18$ & 53 & 85 & 138 & 389 & 270 & 659 & 7 & 17 & 24 \\
\hline & $C D$ & $3-13$ & 4 & 16 & 20 & 80 & 53 & 133 & 2 & 3 & 5 \\
\hline & J & $14-18$ & 15 & 26 & 41 & 291 & 237 & 528 & 4 & 11 & 15 \\
\hline 2012 & O & $3-13$ & 0 & 6 & 6 & 11 & 6 & 17 & 0 & 0 & 0 \\
\hline & & $14-18$ & 8 & 13 & 21 & 56 & 30 & 86 & 0 & 1 & 1 \\
\hline & $T^{2}$ & $3-13$ & 4 & 22 & 26 & 91 & 59 & 150 & 2 & 3 & 5 \\
\hline & & $14-18$ & 23 & 39 & 62 & 347 & 267 & 614 & 4 & 12 & 16 \\
\hline & 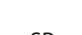 & $3-13$ & 107 & 134 & 241 & 593 & 397 & 990 & 10 & 32 & 42 \\
\hline & Jז & $14-18$ & 154 & 284 & 438 & 1951 & 1225 & 3176 & 42 & 119 & 161 \\
\hline Total & & $3-13$ & 26 & 64 & 90 & 85 & 47 & 132 & 2 & 2 & 4 \\
\hline years) & & $14-18$ & 46 & 86 & 132 & 337 & 188 & 525 & 7 & 17 & 24 \\
\hline & & $3-13$ & 133 & 198 & 331 & 678 & 444 & 1122 & 12 & 34 & 46 \\
\hline & Totar & $14-18$ & 200 & 370 & 570 & 2288 & 1413 & 3701 & 49 & 136 & 185 \\
\hline
\end{tabular}




\section{DISCUSSION}

In the Polish literature, there are no contemporary studies showing the structure of hospitalization and characteristics of children and adolescents referred for neurological and mobility rehabilitation to specialist centres in Poland, such as those in Konstancin, Zakopane-Bystre, Olesno, Repty Śląskie, Świebodzin, Ameryka near Olsztynek and Czarniecka Góra. Similar studies in the foreign literature are also rare. Also, studies about history of such centers in Poland made by us regarding Czarniecka Góra [1, 2, 3] were rare. Recently, Lubecki $[5,6,7]$ published a series of articles on the history of selected Polish orthopaedic-rehabilitation centers, in which he also presented their specialization and scope of therapeutic activities and number of patients.

The centre in Czarniecka Góra (a spa since 1892) is the only rehabilitation centre in Świętokrzyskie Province in south-central Poland, a region with an agricultural-industrial character and tourist attractions (Świętokrzyskie Mountains, significant afforestation, numerous monuments). The area covers $11,710 \mathrm{~km}^{2}$ with 1,282 million inhabitants (2006). After the liberation of Poland in 1945, the center began to specialize in the hospitalization of children and adolescents, treating such illnesses as Heine-Medin disease, tuberculosis of the bones and joints, and the effects of trauma. Since 1972, it has functioned as specialist centre for the combined therapy of cerebral palsy and non-traumatic deforming dorsopathies. The latter has dominated in the structure of admissions of the studied 7 year period, accounting for $52.6 \%$ of all hospitalizations in the stationary wards and up to $80.5 \%$ in the group of 3-18 year-olds. The reasons for this situation are complex and can only be indicated here, referring to the main studies [e.g. 8]. Firstly, most diseases of the spine are scoliosis (including kyphoscoliosis) of various severity and etiology. They belong to the social diseases: over $42 \%$ of the US population suffer from slight scoliosis, while the total of those suffering from scoliosis is $10 \%$ of the societies in developed countries. One case per 1,000 constitutes a serious threat to life due to dysfunction of the respiratory and circulatory system. Secondly, the epidemic of scoliosis in the post-war period in Poland, caused by deficiencies in the diet (rickets) and tuberculosis of bones and joints of children requiring then long-term rehabilitation treatment, gave rise to innovative methods of surgical treatment in Poland by Professors Dega, Gruca, Malawski, Weiss, Dr. Lech Wierusz and others, and the creation of complex rehabilitation has gained international recognition and recommendation of the WHO [6]. Thirdly, a breakthrough which was made in operational methods of scoliosis of the spine (e.g. the method of Shilla - the first such operation in Poland in 2014), and attaining significant achievements, orthopedic centers in Lublin, Łódź and Poznań have resulted in Czarniecka Góra receiving more and more cases of scoliosis (in the earlier period the centre also admitted cases of very neglected children), as well as other cases, such as spinal osteochondrosis (Scheuermann), among others. Assuming a $10 \%$ prevalence of scoliosis in the societies of Western countries, it is estimated that in the population of the Świętokrzyskie Province the number of people with non-traumatic deforming dorsopathies (mainly of the spine), amounts to 120,000 people. A large number of patients outside the Province (132 out of 1,122 children and 525 out of 3,701 admitted in the group of adolescents) among patients with non-traumatic deforming dorsopathies, demonstrates both the referentiality of the centre in the pre - and post-operative therapy in this group of diseases and the great progress made in their treatment. It also indicates the need for highly specialized stationary wards for the rehabilitation of non-traumatic deforming dorsopathies in Poland.

Cerebral palsy, although 5 times less numerous than deforming dorsopathies, is very important due to the severity of disease, the cost of multi-directional and associated hospitalization and healing effects that can be achieved only in a specialist centre such as the ŚRC. Furthermore, the total of 901 patients was not only very large on the background of national data $[9,10]$. It induces to remarks, primarily epidemiological. First of all, the presented material sent from a number of specialist centres (paediatric neurology and neuropaediatric, orthopedics, rehabilitation, etc.) did not differ from the diagnostic criteria adopted worldwide for cerebral palsy. It should be emphasized that this concept, included in the code G80-G81, is a collective term for a non-progressive, multi- and variable symptomatic mobility syndrome caused by damage or disorder in the early stage of brain development, often perinatally $[10,11]$. The presented material is also free from the intended selection, as to the status of a reference center for the Świętokrzyskie province (and more broadly - the surrounding region) and the absence of other centers, almost all cases from that area were hospitalized. Although the fact of hospitalization itself cannot per se constitute grounds for analysis of the incidence and prevalence of G80-G81 in this area, in epidemiological studies, it is a valuable contribution in this regard. A significant (greater than $1 / 4$ of hospitalized in individual years) percentage of patients with cerebral palsy coming from outside the region demonstrates both the referentiality of the centre, and the need for stationary complex rehabilitation of cerebral palsy in the country.

According to consistent data from the world literature, cerebral palsy occurs slightly more often in boys than in girls. Among 445 children from Zielona Góra (14) in Silesia, western Poland, cerebral palsy occurred at a rate of 2.45 per 1,000 live births for boys and 2.0 for girls, respectively ( $\mathrm{p}$ $<0.05$ ). In the presented study, the advantage of boys is even greater (568 versus 333). Assuming that in Świętokrzyskie Province the number of live births is 12,000 per year, assuming a national average of incidence of cerebral palsy 2.2 / 1,000 live births [11-16], it could be assumed that each year in this region 26-27 children are born with this disease. Each of them requires a long-term rehabilitation such as that provided by the ŚRC. The importance of such centers is written in a poignant autobiography by K. Biel-Ziolek who suffers from cerebral palsy [17].

The smallest group (231 hospitalizations), is very diverse regarding the causes and location of the injury requiring rehabilitation of varying intensity, duration and final effectiveness. In all the years in the study, hospitalization is more common in boys $(170=73.5 \%)$, which is consistent with the number of global data with higher injury rates in boys. In this group, the great majority - both in the younger group (42 of 46) and older group (161 of 185) - were residents of Świętokrzyskie Province, which also shows the local health needs in this area.

The expansion of the centre, combined with the renovation of the original hospital building, seriously affected the 
number of both 24 hour and daily admissions. Analysis of admissions during this period was also a convenient starting point for determining the load of individual wards, as well as assessing the rehabilitation needs of the admissions for each pathology group and age of the ill children and adolescents as illustrated quantitatively in the results. They coincide with our many years of experience - and clarify them - referring to the full load of full-profile treatment and rehabilitation for children and adolescents. The biggest needs for admissions concern, in all groups of diseases, adolescents aged 14-18, which were so serious that, despite the ongoing renovation, there was an increase in the number of admissions in this group at the expense of the youngest. This could be explained by both an increased concern for the appearance and health of adolescents, as well as the beneficial effects of rehabilitation therapy in the younger age group, generally benefiting earlier from rehabilitation in the SRC. The transitional deficit of places in the ŚRC has become a 'natural experiment' showing the most urgent health needs in this group of diseases. It also demonstrated the necessity for reducing health inequality in the social and regional access to specialized therapeutic and rehabilitation procedures for these diseases.

\section{CONCLUSIONS}

1. Analysis of the large material concerning 5,955 children and adolescents aged 3-18 years with impaired mobility, hospitalized in the period of 7 years (2007-2013) in a regional specialist rehabilitation centre, revealed a number of quantitative data helping in the analysis of the epidemiological situation of this group of diseases, as well as assessing the need for comprehensive rehabilitation activities in this field and evaluation of the optimal use of stationary treatment options.

2. The greatest needs in terms of admissions to the SRC concern the group of young people aged 14-18 in all 3 analyzed etiological groups of diseases, which resulted in the full use of hospital beds.

3. In the analyzed period, the total number of admissions was significantly reduced due to renovation and expansion of the SRC. However, at the same time, in 2 etiological groups (cerebral palsy, deforming dorsopathies) the number of hospitalized adolescents aged 14-18 years increased at the expense of reducing the number of admissions of younger patients ( $3-13$ years).

4. Full use of places and the very beneficial effects of combined rehabilitation in the Świętokrzyskie Rehabilitation Centre in Czarniecka Góra indicate the need for the creation of similar specialist centres at the provincial and even regional level, as an element of levelling the existing inequalities in health care.

\section{REFERENCES}

1. Grabowski ML. Świętokrzyskie Centrum Rehabilitacji w Czarnieckiej Górze - potencjał i możliwości rozwoju. In: Jędrzejczyk I, Regionalny program rozwoju na tle strategii Unii Europejskiej Europa 2020 z uwzględnieniem roli ubezpieczeń na przykładzie Województwa Świętokrzyskiego. Poznań, Iuris, 2012.p.301-304. (in Polish)

2. Werens A. Czarniecka Góra - historia, czas dzisiejszy - perspektywy rozwoju. In: Jędrzejczyk I, Regionalny program rozwoju na tle strategii Unii Europejskiej Europa 2020 z uwzględnieniem roli ubezpieczeń na przykładzie Województwa Świętokrzyskiego. Poznań, Iuris, 2012. p.289-299. (in Polish)

3. Werens A. Czarniecka Góra. Historia uzdrowiska. Końskie, Arslibris, 2005.

4. International Statistical Classification of Diseases and Health Related Problems. 10th ed. (WHO, 1992). Kraków, Vesalius, 1999.

5. Lubecki M. The role of orthopedic-rehabilitation centers in the Polish model of rehabilitation in the second half of the twentieth century. Hygeia Public Health. 2011; 46(2): 249-255.

6. Lubecki M. The Polish model of rehabilitation accepted and recommended by WHO. Hygeia Public Health. 2011; 46(4): 506-515.

7. Lubecki M. Historia wybranych ośrodków rehabilitacyjnoortopedycznych w Polsce. Ośrodek rehabilitacyjno-ortopedyczny w Świebodzinie. Hygeia Public Health. 2012; 47(1): 113-131. (in Polish)

8. Wilczyński J. Boczne skrzywienia kręgosłupa. Rozpoznanie i korekcja. Część 1. Kielce, Wszechnica Świętokrzyska, 2000. (in Polish)

9. Gorelick P.B, Alter M. (eds.). Handbook of Neuroepidemiology. New York, Martin Dekker, 1994

10. Mutch L, Alberman E, Hagberg B, Kodoma K, Perat M. Cerebral palsy epidemiology: Where are we now and where are we going. Adnotations. Rev Med Child Neurol. 1992; 34: 547-555.

11. Michałowicz R. (eds.). Mózgowe porażenie dziecięce. 3rd ed. Warszawa, PZWL, 2001. (in Polish)

12. Gryglewicz D, Milewska D. Epidemiologia chorób układu nerwowego. In: Mazur R. (eds.). Neurologia kliniczna. Gdańsk, Via Medica, 2005.p.29-45. (in Polish)

13. Galas-Zgorzalewicz B, Gurda B, Kluczyński A. i wsp. Epidemiologia mózgowego porażenia dziecięcego. In: Dni Neurologii Dzieci i Młodzieży: Postępy w rehabilitacji w chorobach układu nerwowego u dzieci. Poznań, 1993.p.46-49. (in Polish)

14. Zgorzalewicz B, Mieszczanek T, Zgorzalewicz M. Epidemiologia opisowa mózgowego porażenia dziecięcego. Ortop Traumatol Rehabil. 2001; 3(4): 467-471. (in Polish)

15. Mieszczanek T. Selected epidemiologic aspects of cerebral palsy in the population of children and adolescents in west-east Poland. Neurol Dziec. 2003; 12(24): 13-22.

16. Kułak W, Sobaniec W. Cerebral palsy in north-eastern Poland. J Pediatr Neurol. 2004: 2(2): 79-84.

17. Biel-Ziółek K. Ciernista droga nadziei. Lublin, PTN, 1997. (in Polish) 